Pobrane z czasopisma Annales I - Philosophy and Sociology http://philosophia.annales.umcs.pl Data: 26/04/2023 12:28:37

DOI: $10.17951 / \mathrm{i} .2018 .43 .1 .145-158$

\begin{tabular}{lcr}
\hline \multicolumn{2}{c}{ A N N A LES } \\
UNIVERSITATIS M A R I A E C URIE-SK L ODOWSK A \\
LOL. XLIII, 1 & SECTIO I & 2018 \\
\hline
\end{tabular}

TATIANA KANASZ

ORCID ID: https://orcid.org/0000-0001-7389-5683

Akademia Pedagogiki Specjalnej im. Marii Grzegorzewskiej

\title{
Zmiany kultury emocjonalnej pracowników socjalnych w Polsce*
}

Changes of Emotional Culture of Social Workers in Poland

\section{WPROWADZENIE}

Wiodącym problemem niniejszego opracowania jest ukazanie istoty oraz przemian kultury emocjonalnej pracowników socjalnych w Polsce współczesnej. Doniosłość podjętego zagadnienia wynika z faktu, że jakość pomocy społecznej i pracy socjalnej wiąże się m.in. z umiejętnościami interpersonalnymi, etycznymi oraz społecznymi profesjonalistów, w tym z umiejętnością kontroli nad emocjami czy zarządzaniem emocjami. W 2012 r. autorka podjęła zagadnienie emocji w zawodzie pracownika socjalnego w osobnym projekcie badawczym, realizowanym we współpracy z I. Zielińską ${ }^{1}$. Nowość proponowanej publikacji polega na ponownym odczytaniu roli emocji w zawodzie pracownika socjalnego w oparciu o badania empiryczne, realizowane także przez innych badaczy.

Nie ulega wątpliwości, że sfera pomocy może być problematyzowana w kategorii emocji, które określa się ważnym elementem ludzkiego doświadczenia.

\footnotetext{
* Praca powstała w ramach grantu nr BSTP 40/16-I, Akademia Pedagogiki Specjalnej im. M. Grzegorzewskiej.

1 T. Kanasz, Badania emocji społecznych pracowników socjalnych, „Praca Socjalna” 2014, nr 1, s. 96-112; eadem, Poczucie zadowolenia z wykonywanej pracy w opiniach pracowników socjalnych, [w:] M. Mikołajczyk (red.), Pomoc społeczna i praca socjalna - różne oblicza $i$ zadania, Warszawa 2014, s. 13-28; T. Kanasz, I. Zielińska, Emotional Labour of the Polish Social Workers: The Study in Sociology of Emotions, "Polish Sociological Review" 2017, No. 3, s. $337-351$.
} 
Pobrane z czasopisma Annales I - Philosophy and Sociology http://philosophia.annales.umcs.pl Data: 26/04/2023 12:28:37

Emocje podlegają społecznemu ustrukturowaniu ${ }^{2}$, zatem dyskusje wokół pomocy również ukazują różnicę postaw poszczególnych warstw społecznych w tym zakresie. Odmienna jest perspektywa osób oraz instytucji świadczących pomoc oraz tych, którzy są jej odbiorcami³. Pytania godne uwagi w tym obszarze dotyczą poczucia efektywnej i sprawiedliwej pomocy, a także szacunku i godności zarówno osób oferujących pomoc, jak i osób ją przyjmujących, czyli pracowników i klientów pomocy społecznej. Problematyka pomocy jest związana z dwiema kategoriami emocji: tymi nacechowanymi pozytywnie oraz takimi, które są bardziej kłopotliwe, wywołują niepokój moralny. Niesienie pomocy innym często daje poczucie satysfakcji, ale też w pewnych sytuacjach może wywołać poczucie winy, złości czy wstydu ${ }^{4}$.

Wychodzę z założenia, że emocjonalna kultura pracowników socjalnych wiąże się z kulturą organizacyjną i instytucjonalną. Profesjonalna pomoc społeczna od lat pełniła głównie funkcję osłonową (opiekuńczą). Dopiero w okresie transformacji systemowej oraz po przystąpieniu Polski do Unii Europejskiej zostały podjęte dyskusje na temat pomocy aktywizującej, czyli takiej, która ma prowadzić do usamodzielnienia klienta. Równolegle do polityki aktywizacji i integracji rozwijało się zawodowe przygotowanie pracowników socjalnych. Ponadto zaczął odradzać się sektor społeczeństwa obywatelskiego, pojawiły się liczne inicjatywy oraz organizacje niosące pomoc różnym kategoriom społecznym.

Perspektywa kulturowa dostarcza szerszego kontekstu do analizy przemian społeczeństwa polskiego ${ }^{5}$. E. Tarkowska zwróciła uwagę na złożoność czynników zmiany społecznej: rolę lokalnych i globalnych zjawisk i procesów, oddziaływanie nie tylko teraźniejszości, ale także przeszłości. Do lokalnych czynników odnosiła ona m.in. wpływ charakterystycznych dla PRL-u ,specyficznych uwarunkowań systemowych na: zachowania, mentalność, styl życia, poczucie zależności

2 P. Binder, H. Palska, W. Pawlik, Zaproszenie do socjologii emocji, [w:] P. Binder, H. Palska, W. Pawlik (red.), Emocje a kultura i życie społeczne, Warszawa 2009, s. 10.

3 Por. K. Górniak, Bieda i wykluczenie spoleczne w perspektywie (dobroczynnych) organizacji pozarzadowych, [w:] E. Tarkowska (red.), Dyskursy ubóstwa $i$ wykluczenia społecznego, Warszawa 2013, s. 301-339; A. Kalbarczyk, Wizje biedy $i$ wykluczenia społecznego w praktyce polskiego systemu pomocy społecznej, [w:] E. Tarkowska (red.), op. cit., s. 227-299; E. Tarkowska, Biedni o biedzie, biedni o sobie, [w:] E. Tarkowska (red.), op. cit., s. 381-436.

4 T. Kanasz, Badania emocji społecznych ...; eadem, Poczucie zadowolenia ...; eadem, Buying Food for a Hungry Person in Poland: A Case of an Internet Discussion, "Studies in Global Ethics and Global Education" 2016, Vol. 6(1), s. 54-67; eadem, Pomoc osobom doświadczajacym ubóstwa w świetle socjologii emocji, „Praca Socjalna” 2016, nr 4, s. 49-65; T. Kanasz, I. Zielińska, op. cit., s. 337-351.

E. Tarkowska, O potrzebie uwzględnienia kultury raz jeszcze, [w:] P. Kozłowski, H. Domański (red.), Po 20 latach: polska transformacja z perspektywy ekonomicznej, socjologicznej i prawniczej, Warszawa 2010, s. 203-216. 
Pobrane z czasopisma Annales I - Philosophy and Sociology http://philosophia.annales.umcs.pl Data: 26/04/2023 12:28:37

Zmiany kultury emocjonalnej pracowników socjalnych w Polsce

i przymusu, brak zaufania i poczucie braku wpływu na otaczającą rzeczywistość”6. Inną klasę czynników badaczka wiązała z globalnymi procesami o charakterze zmian cywilizacyjnych, w tym z wpływem nowych technologii komunikacyjnych i informacyjnych, rynku, reklamy oraz konsumpcji, powodujących kształtowanie aspiracji, wartości i postaw Polaków, włącznie z orientacją indywidualistyczną? Wymienione czynniki są istotne również dla zrozumienia kultury emocjonalnej pracowników socjalnych.

\section{KONCEPCJA KULTURY EMOCJONALNEJ}

Pojęcie kultury emocjonalnej wprowadził S. Gordon ${ }^{8}$, który rozróżnił uczucia społeczne (trwające dłużej) od (krótkotrwałych) emocji. Kultura emocjonalna obejmuje słowniki emocji, normy oraz przekonania dotyczące emocji. Słowniki emocji to „Kulturowo przyjęte i reprodukowane kompleksy słownictwa używanego dla określenia emocji. Są wyrazistymi, przyjętymi w danej społeczności etykietami językowymi odsyłającymi do ważnych, z uwagi na interakcje społeczne, emocji"9. Normy regulują ekspresję emocji oraz sposób ich odczuwania. Wiążą się z przekonaniami na temat emocji (np. ich ważnością). Pojęcie kultury emocjonalnej Gordona zainspirowało A.R. Hochschild ${ }^{10}$ do stworzenia koncepcji pracy nad emocjami (zarządzania emocjami), polegającej na tłumieniu lub wywoływaniu określonych emocji w konkretnej sytuacji interakcji społecznej. Reguły zarządzania uczuciami mają podłoże ideologiczne. W każdym zawodzie funkcjonują odpowiednie reguły i wiążą się z określoną ideologią. Pracownicy zarządzają emocjami na różne sposoby: wykonują pracę powierzchowną lub głęboką, mniej lub bardziej utożsamiając się ze swoją rolą. Ponadto amerykańska socjolog wyróżniła dwa zbiory norm: reguły odczuwania oraz reguły wyrażania emocji. Stanowią one:

[...] odbicie ogólniejszej kultury emocji i ideologii emocjonalnej, która steruje zachowaniem w określonej sytuacji. Co więcej, struktury szerszego kontekstu organizacyjnego, zwłaszcza podział pracy i rozkład władzy, również określają reguły odczuwania i wyrażania emocji przez jednostki.

6 Ibidem, s. 205.

Ibidem.

8 S. Gordon, Social Structural Effects on Emotions, [w:] T. Kemper (ed.), Research Agenda for Sociology of Emotions, New York 1990, s. 145-179.

9 A. Czerner, E. Nieroba, Język socjologów emocji-subiektywny przewodnik, [w:] A. Czerner, E. Nieroba (red.), Studia z socjologii emocji, Opole 2011, s. 344.

10 A.R. Hochschild, Ideology and Emotion Management: A Perspective and Path for Future Research, [w:] T.D. Kemper (ed.), Research Agendas in the Sociology of Emotions, Albany 1990, s. 117-142; idem, Zarzadzanie emocjami. Komercjalizacja ludzkich uczuć, Warszawa 2009. 
[...] Reguły odczuwania i wyrażania zostawiają na ogół osobom posiadającym władzę szerszy margines swobody niż tym, które mają tej władzy mniej ${ }^{11}$.

Kultura emocjonalna obejmuje sposoby:

[ ...] ekspresji emocji i motywowane emocjami zachowania, układające się w łańcuchy scenariuszy emocjonalnych. Przebieg tych scenariuszy reguluje system norm emocjonalnych i oczekiwań normatywnych dotyczących emocji, zakorzeniony w zbiorach wyobrażeń i przekonań na temat emocji, podzielanych za pomocą określonego języka opisu doświadczeń emocjonalnych ${ }^{12}$.

Do przejawów specyficznej dla danego społeczeństwa kultury emocjonalnej należą zatem zachowania ludzi oraz treści medialne, motywy obecne w wytworach kultury popularnej, dyskurs naukowy i popularno-naukowy, a także pojęcia, w które ujmuje się określone uczucia, opowiadając o przeżyciach ${ }^{13}$. Kulturę emocjonalną przyswaja się w trakcie socjalizacji, która jest związana ze strukturą społeczną.

W ramach kultury emocjonalnej Gordon ${ }^{14}$ ulokował dwie orientacje: instytucjonalną oraz impulsywną. Pierwsza cechuje osoby, które kontrolują swoje uczucia i ekspresję, jest ona skupiona wokół norm związanych z tradycją i instytucją, zawiera większy słownik emocji, obejmuje bardziej złożone emocje (np. współczucie, poważanie, pogardę, oburzenie). Druga orientacja zawiera spontaniczne zachowania emocjonalne, a za źródło norm uznaje rówieśników i media masowe; obejmuje emocje pierwotne (np. irytację, zaskoczenie, strach, podniecenie), posiada mniejszy słownik emocji. Gordon zauważył, że orientacja instytucjonalna jest ważna w relacjach długotrwałych, natomiast orientacja impulsywna może być przydatna w sytuacjach przejściowych ${ }^{15}$.

Biorąc pod uwagę definicję kultury emocjonalnej Gordona, można uznać, że kultura emocjonalna pracowników socjalnych obejmuje słowniki emocji, przekonania oraz normy towarzyszące udzielaniu pomocy. Jest ona regulowana odpowiednią ustawą i kodeksem etycznym. Kultura emocjonalna pracowników socjalnych obejmowałaby nie tylko emocje towarzyszące wykonywanej pracy (w tym stosunek do klientów ośrodków pomocy społecznej), ale także sposoby radzenia sobie z emocjami, umiejętność pokonywania stresu. Istotnym elementem kultury

11 J.H. Turner, J.E. Stets, Socjologia emocji, Warszawa 2009, s. 52.

12 M. Sawicka, Pojęcie kultury emocjonalnej jako narzędzie analizy socjologicznej, „Kultura i Społeczeństwo" 2015, nr 1, s. 188.

13 Ibidem, s. 192-193.

14 S. Gordon, Institutional and impulsive orientations in selectively appropriating emotions to self, [w:] D.D. Franks, E. Doyle McCarthy (eds.), The Sociology of Emotions, Greenwich 1989, s. $115-135$.

15 J.H. Turner, J.E. Stets, op. cit., s. 49. 
Pobrane z czasopisma Annales I - Philosophy and Sociology http://philosophia.annales.umcs.pl Data: 26/04/2023 12:28:37

emocjonalnej pracowników socjalnych jest duma z wykonywanej pracy oraz prestiż zawodu. Należy jednak zauważyć, że w praktyce kultura emocjonalna może być modyfikowana pod wpływem czynników sytuacyjnych.

Badanie kultury emocjonalnej obejmuje m.in. analizę tekstów (np. publikacji naukowych, dokumentów prawnych, tekstów instytucjonalnych, medialnych). W zrozumieniu językowego opisu doświadczeń emocjonalnych pracowników może być pomocna obserwacja ich codziennej pracy oraz wszelkiego rodzaju wypowiedzi (pozyskiwanych np. w drodze wywiadu badawczego lub wyrażane $\mathrm{w}$ formie pisemnej w postaci dziennika emocji). Niniejszy artykuł ogranicza się do zasygnalizowania wybranych aspektów pomocy związanych ze sferą emocji, które mogą posłużyć do dalszej dyskusji na temat roli emocji w sferze pomocy oraz - w kontekście transformacji systemowej - zmian kultury emocjonalnej profesjonalistów.

Dlaczego zagadnienie kultury emocjonalnej pracowników socjalnych jest warte naukowego poznania? Można wymienić trzy podstawowe powody. Po pierwsze, we współczesnych społeczeństwach zapotrzebowanie na zawody pomocowe stale rośnie. W tym kontekście ważnym zadaniem społecznym jest odbudowanie prestiżu takich zawodów. Po drugie, kultura emocjonalna profesjonalistów ma związek z ich dobrostanem, poczuciem satysfakcji ze względu na niesioną drugiemu człowiekowi pomoc. W tym wymiarze niezbędne są działania zapobiegające wypaleniu zawodowemu pracowników. Po trzecie, sposób zarządzania emocjami pracowników socjalnych może wpłynąć na przebieg interakcji z klientem, jego odbiór odnośnie do uzyskiwanej pomocy. Kultura emocjonalna konkretnej grupy zawodowej jest bowiem częścią kultury emocjonalnej społeczeństwa.

\section{INSTYTUCJONALIZACJA POMOCY}

Początki pomocy społecznej w Polsce sięgają lat 20. XX w., czyli ustawy o opiece społecznej z 1923 r. oraz Studium Pracy Społeczno-Oświatowej H. Radlińskiej z 1925 r. ${ }^{16}$ Służby społeczne w Polsce nie rozwijały się w sposób ciągły. Przerwanie tradycji nastąpiło w okresie II wojny światowej, a następnie w okresie stalinizmu ${ }^{17}$. W Polskiej Rzeczypospolitej Ludowej, podobnie jak w innych krajach postkomunistycznych, służby społeczne funkcjonowały na obrzeżach życia publicznego. W Polsce Ludowej problemy społeczne (ubóstwo, bezrobocie)

16 A. Niesporek, Ł. Trembaczowski, T. Warczok, Granice symboliczne. Studium praktyk kulturowych na przykładzie działań zawodowych pracowników socjalnych, Kraków 2013.

17 T. Kaźmierczak, Pracownicy socjalni, kapitał ludzki, profesjonalna praktyka, [w:] M. Rymsza (red.), Pracownicy socjalni i praca socjalna w Polsce. Między służba społeczną a urzędem, Warszawa 2012, s. 159-186. 
Pobrane z czasopisma Annales I - Philosophy and Sociology http://philosophia.annales.umcs.pl Data: 26/04/2023 12:28:37

były ukrywane przed opinią publiczną. Oficjalnie deklarowano, że nie występują. W rzeczywistości zaś bezrobocie miało charakter ukryty - istniało $\mathrm{w}$ formie przerostu zatrudnienia oraz nieproduktywnych miejsc pracy. Ponieważ nie rozpoznawano problemów społecznych, marginalizowano również instytucje pomocy. Opieka społeczna nie była eksponowana, należała do służby zdrowia ${ }^{18}$.

Ostatecznie ustawa z 1990 r. „,uczyniła z pomocy społecznej ważną i rozpoznawalną instytucję polityki społecznej państwa, a z pracowników socjalnych - wyodrębnioną profesję"19. Od początku służby pomocy społecznej miały realizować dwie podstawowe funkcje: osłonowo-opiekuńczą oraz aktywizująco-integrującą. W praktyce pierwsza z nich zdominowała działania pracowników socjalnych, którzy przyznawali zasiłki i byli przez pryzmat tej działalności postrzegani w środowisku społecznym ${ }^{20}$.

Polityka działań aktywizujących przyspieszyła w drugiej dekadzie transformacji. Zbiegło się to z wejściem Polski do Unii Europejskiej oraz z wdrażaniem unijnych priorytetów w polityce społecznej ${ }^{21}$. W 2003 r. Departament Pomocy Społecznej zmienił nazwę na Departament Pomocy i Integracji Społecznej. W 2004 r. weszła w życie ustawa o pomocy społecznej, która wprowadziła kontrakt socjalny jako narzędzie wsparcia warunkowego ${ }^{22}$. W praktyce metoda kontraktu stała się narzędziem pozbywania się „trudnych” klientów zamiast ich usamodzielniania ${ }^{23}$. Niemniej specjaliści i naukowcy utrzymują, że funkcja aktywizująca powinna być uzupełnieniem funkcji osłonowej. W przypadku form pracy aktywizującej wskazują oni na rolę pracy indywidualnej i środowiskowej ${ }^{24}$.

Ważną zmianą w obszarze kultury emocjonalnej pracowników socjalnych stała się superwizja pracy socjalnej, która miała na celu m.in. udzielanie wsparcia pracownikowi oraz zapobieganie wypaleniu zawodowemu. Traktujące o tym rozporządzenie Ministra Rodziny, Pracy i Polityki Społecznej z dnia 2 grudnia 2016 r. w sprawie superwizji pracy socjalnej zostało opublikowane 20 grudnia $2016 \mathrm{r}$.

Ten skrótowo zarysowany kontekst instytucjonalny pomaga zrozumieć co najmniej dwie istotne zmiany. Pierwsza kwestia dotyczy warunków i sposobów udzielania pomocy, a druga ukazuje dalszą profesjonalizację zawodu pracownika socjalnego oraz docenienie tego obszaru pracy, który wiąże się z zarządzaniem emocjami.

18 Zob. M. Rymsza, Pracownicy socjalni i praca socjalna w Polsce, [w:] M. Rymsza (red.), op. cit., s. 15.

19 Ibidem.

$20 \quad$ Ibidem, s. 18.

${ }_{21}$ Idem, W stronę pracy środowiskowej i nowych ról zawodowych pracowników socjalnych, [w:] M. Rymsza (red.), op. cit., s. 204.

22 Ustawa z dnia 12 marca 2004 r. o pomocy społecznej (Dz.U. nr 64, poz. 593), art. 108.

$23 \quad$ M. Rymsza, $W$ strone pracy środowiskowej...

24 Ibidem. 
Pobrane z czasopisma Annales I - Philosophy and Sociology http://philosophia.annales.umcs.pl Data: 26/04/2023 12:28:37

Zmiany kultury emocjonalnej pracowników socjalnych w Polsce

151

\section{KULTURA EMOCJONALNA PROFESJONALISTÓW}

W dyskursie naukowym dotyczącym pracowników socjalnych wzrasta znaczenie perspektywy emocji. Kultura emocjonalna pracowników socjalnych obejmuje ich stosunek do własnego zawodu i klientów pomocy społecznej, a także wyznawane wartości oraz przekonania i sposoby zarządzania swoimi emocjami. Spróbuję odtworzyć główne charakterystyki zawodu pracownika socjalnego z perspektywy kultury emocjonalnej. Należy zauważyć, że będzie to ogląd niewyczerpujący, ponieważ celem przywoływanych dalej publikacji nie było eksplorowanie danego zagadnienia w sposób bezpośredni.

Ze względu na to, że kultura emocjonalna pracowników jest kształtowana w procesie socjalizacji, warto zacząć od wyboru takiej, a nie innej ścieżki zawodowej. Porównując motywacje wyboru pracownika socjalnego w 1988 r. (przypadek, świadomy wybór, zainteresowania) oraz 2010 r. (przypadek, chęć pomagania innym, samorealizacja), można zauważyć, że poza dominującą w obu okresach odpowiedzią „przypadek”, znaczenie mają emocjonalnie nacechowane motywy, jak „,chęć pomagania innym” i „samorealizacja” ${ }^{25}$. Także badania E.M. Florys ${ }^{26}$ pokazują pozy tywnie wartościowaną emocjonalną identyfikację z zawodem (wśród badanych pracowników socjalnych przeważa pozytywny związek emocjonalny ze swoją kategorią zawodową).

Inaczej wygląda ogólna ocena postaw pracowników socjalnych:

Z badań dotyczących orientacji społecznych respondentów, przeprowadzonych w 1988 roku, wyłania się obraz pracownika socjalnego jako osoby raczej nieufnej, opornej na zmiany, bardziej oportunistycznej niż odpowiedzialnej za siebie i raczej autorytarnej niż otwartej i tolerancyjnej. 22 lata nie wpłynęły znacząco na zmiany postaw pracowników socjalnych w wyżej wymienionych obszarach $^{27}$.

Należy podkreślić, że występuje zróżnicowanie postaw pracowników socjalnych w zależności od miejsca i stażu pracy. Wyższy poziom ufności wykazują pracownicy socjalni zatrudnieni w placówkach specjalistycznych, niższy - pracownicy z ośrodków pomocy społecznej ${ }^{28}$. Przywoływane badanie pokazuje, że wśród pracowników socjalnych rośnie poczucie wiary we własne siły, aczkolwiek poczucie sprawstwa jest większe u młodszych pracowników (do 25. roku życia),

25 M. Łuczyńska, Pracownicy socjalni w procesie zmian - na podstawie badań z 1988, 1995 i 2010 roku, [w:] M. Rymsza (red.), op. cit., s. 37-92.

26 E.M. Florys, Identyfikacja z zawodem pracowników socjalnych, „Annales UMCS. Sectio J” 2016, nr 1, DOI: http://dx.doi.org/10.17951/j.2016.29.1.67, s. 76.

27 M. Łuczyńska, op. cit., s. 116.

28 Ibidem, s. 121. 
z krótszym stażem pracy (do 2 lat) ${ }^{29}$. Ponadto wyniki badania wskazują na deklarowany wysoki poziom kompetencji pracowników socjalnych, ale zarazem ujawniają poczucie bezsilności (brak wpływu, autonomii) w realizacji zadań ${ }^{30}$. Za najważniejsze wartości w pracy socjalnej uznaje się odpowiedzialność, godność i tolerancję $e^{31}$. Są one zbieżne z wartościami zawartymi w profesjonalnych normach. Z Kodeksu Etycznego Polskiego Towarzystwa Pracowników Socjalnych wyłaniają się następujące cechy pracowników: posiadanie wysokiego morale zawodowego i osobistego, doskonalenie kwalifikacji zawodowych, dbanie o dobro klienta oraz przyjęcie odpowiedzialności za jakość i zakres zadań, które pracownik socjalny wykonuje lub zleca ${ }^{32}$. Obowiązkiem pracownika jest przeciwstawianie się praktykom niehumanitarnym lub dyskryminującym wobec osób lub grup ${ }^{33}$.

Kultura emocjonalna pracowników socjalnych jest zakorzeniona w strukturze społecznej. Spośród cech charakteryzujących środowisko zawodowe pracowników socjalnych D. Trawkowska ${ }^{34}$ wskazuje m.in. na feminizację (przewagę kobiet w strukturze zatrudnienia), wyższe wykształcenie, starszy wiek oraz doświadczanie problemów we własnych rodzinach. Ostatnia cecha zarówno ułatwia empatyczne zrozumienie problemów klienta, jak i sprzyja projektowaniu własnych rozwią$z^{2} a^{35}$. Mentalność środowiskowa wyraża się w obecności podwójnych standardów, akceptacji działań pozornych, praktyk dyskryminujących, co ma uwarunkowania lokalne - badaczka wskazuje w tym zakresie na „słabość zasobów, trudną sytuację na rynku pracy, słabą pozycję ośrodka: jego kierownictwa wobec władz, obawę przed mediami" ${ }^{36}$. Uwagę zwraca się także na zewnątrzsterowność pracowników socjalnych, która stoi w sprzeczności z ideą empowermentu w pracy socjalnej ${ }^{37}$. Należy dodać, że pojęcie empowerment ma charakter ideologiczny, ponieważ posiada emancypacyjny i regulatywny potencja ${ }^{38}$. Upodmiotowienie oznacza zdolność panowania nad sobą i swoim życiem. Jednak standardy życia samodzielnego i zgodnego z normami wyznaczają profesjonaliści. Również starzenie się kategorii

29 Ibidem, s. 124.

30 Ibidem, s. 137.

31 Ibidem, s. 140.

32 Kodeks Etyczny Polskiego Towarzystwa Pracowników Socjalnych, http://federacja-socjalnych.pl/images/PDF/kodeks_etyczny.pdf [dostęp: 25.04.2018].

33 Ibidem.

34 D. Trawkowska, Pracownicy socjalni jako środowisko zawodowe. Portret czy portrety pracowników socjalnych? (komentarz), [w:] M. Rymsza (red.), op. cit., s. 147.

35 Ibidem.

36 Ibidem, s. 149.

37 M. Bieńko, Dylematy profesji i roli w refleksyjnym projekcie tożsamości współczesnego pracownika socjalnego na przykładzie pracowników powiatowych centrów pomocy rodzinie, [w:] M. Rymsza (red.), op. cit., s. 93-120; D. Trawkowska, op. cit., s. 151.

38 A. Niesporek, Ł. Trembaczowski, T. Warczok, op. cit., s. 61. 
Pobrane z czasopisma Annales I - Philosophy and Sociology http://philosophia.annales.umcs.pl Data: 26/04/2023 12:28:37

Zmiany kultury emocjonalnej pracowników socjalnych w Polsce

zawodowej pracowników socjalnych ${ }^{39}$ może warunkować tempo zmiany kultury emocjonalnej - osoby z dłuższym stażem pracy mogą być bardzo przywiązane do dawnych praktyk oraz podejścia do klientów.

Do ważnych warunków kultury emocjonalnej analizowanej grupy zawodowej należy społeczny szacunek. Tymczasem problemem pracowników socjalnych w Polsce jest niski prestiż zawodu, z którym wiążą się zarówno niskie zarobki, jak i często negatywny wizerunek pracownika socjalnego w mediach, a także przypadkowość wyboru zawodu przez znaczną część osób. „Pracownicy socjalni budują swoją tożsamość zawodową bardziej jako urzędnicy publicznych placówek pomocy społecznej"’40. Kapitałem kulturowym pracowników jest moralna wyższość nad klientami, a także wsparcie innych współpracowników. „Uczucia są dla pracowników socjalnych niezbędnym elementem pracy z ludźmi. Nie może pracować z ludźmi ktoś, kto nie kieruje się uczuciami. [...] Pracownicy socjalni to »pomagacze« »spieszący z pomocą«, gdyż »czują《 taką potrzebę. Praca socjalna przybiera charakter misji moralnej"4l.

Normatywne oczekiwania wobec okazywania emocji dotyczą w dużym stopniu kontaktów pracowników socjalnych z klientami pomocy społecznej. W praktyce pracownicy socjalni stosują różne kryteria oceny (ramy ideologiczne) w stosunku do różnych kategorii klientów. Wobec tych, których określają jako „zasługujących na pomoc", przyjmują ideologię socjaldemokratyczną, widząc przyczyny trudnej sytuacji w czynnikach strukturalnych, natomiast wobec klientów „roszczeniowych” wykazują postawę neoliberalną, odwołującą się do odpowiedzialności jednostko$w j^{42}$. Ponadto w wykonywanie obowiązków pracownika jest wpisana funkcja kontrolna. Czasem przyjmuje ona postać dyscyplinującą. Pracownicy wpływają na charakter interakcji z klientem ośrodka pomocy społecznej. Przejawia się to w języku, którego używają, oraz w strukturze rozmowy. Przykładem jest zdawkowe otwarcie interakcji („Dzień dobry”) lub jego brak, dyktowanie klientowi wymaganego oświadczenia, użycie administracyjnego języka (np. „Jest Pan/i powyżej kryterium dochodowego") w celu zniechęcenia klienta, który w efekcie rezygnuje ze swych oczekiwań ${ }^{43}$. Taka powściągliwość pracownika może być przejawem jego postawy obronnej przed ewentualnym wyczerpaniem emocjonalnym.

Przerwanie tradycji w rozwoju służb społecznych przyczyniło się m.in. do kruchości kapitału ludzkiego pracowników socjalnych ${ }^{44}$. Odwołując się do

\footnotetext{
M. Łuczyńska, op. cit.

Ibidem.

Ibidem, s. 213.

Ibidem, s. 135-136.

43 A. Niesporek, Ł. Trembaczowski, T. Warczok, op. cit.

44 T. Kaźmierczak, op. cit.
} 
aksjologicznego wymiaru pracy socjalnej, zauważono słabo zinternalizowaną zasadę podmiotowego traktowania klientó $\mathrm{w}^{45}$. Nierzadkie w środowisku profesjonalistów niosących pomoc jest paternalistyczne podejście do klienta, które przejawia się przekonaniem ,ja wiem lepiej”. Z jednej strony wielu ma przekonanie, że państwo jest odpowiedzialne za różne sfery funkcjonowania jednostek i rodzin, z drugiej zaś rośnie świadomość znaczenia pracy środowiskowej, organizowania społeczności lokalnej. W realizacji funkcji pomocy chodzi nie tyle o działanie doraźne, ile o takie działanie, które usamodzielnia beneficjenta pomocy. W tych ostatnich przypadkach pracownicy czerpią satysfakcję z wykonywanej pracy.

Praca emocjonalna w pomocy społecznej wymaga zaangażowania, a to wiąże się zarówno z kosztami emocjonalnymi (np. ryzyko wypalenia się, oburzenie, poczucie winy, poczucie bezradności), jak i profitami emocjonalnymi (np. poczucie dumy, kiedy udało się komuś pomóc, wdzięczność klienta). Od pracownika socjalnego wymagane jest okazywanie współczucia, ukrycie własnej niechęci czy niezadowolenia, okazanie empatii (zrozumienia emocji klientów). W praktyce jednak nieraz zdarzają się kontakty z agresywnym klientem. Sposoby poradzenia sobie z emocjami negatywnymi mogą być związane ze stosunkiem do pracy. Osoby pracujące z pasją łatwiej pokonują trudności niż osoby doświadczające wypalenia zawodowego. Także dłuższy staż pracy pracownika socjalnego przyczynia się do bardziej efektywnego zarządzania trudnymi emocjami ${ }^{46}$.

Istotnym zagadnieniem, pokrywającym się z obszarem kultury emocjonalnej, jest problem deformacji zawodowej pracownika socjalnego ${ }^{47}$.

Chodzi tu o pewne zniekształcenia zawodowe ujawniające się w postaci: utraty poczucia służby drugiemu człowiekowi na rzecz realizacji wymogów zawodowych, utraty motywacji do pracy, osłabienia zaangażowania, rutynowego wykonywania zadań, aż do poczucia stereotypowego postrzegania klientów i wypalenia zawodowego ${ }^{48}$.

Deformacja zawodowa dokonuje się wraz ze stażem pracy. Oprócz wielu rozmaitych czynników oddziałujących na powstawanie deformacji roli zawodowej, warto wspomnieć o ogromie ludzkich nieszczęść, z którymi pracownik socjalny styka się w praktyce. Ogromne znaczenie mają umiejętności radzenia sobie ze stresem. Jak pokazują wyniki badania T. Zbyrad, zawód pracownika socjalnego jest bardzo stresogenny, z czasem osłabienie zaangażowania pracowników prowadzi do poczucia zmęczenia ze względu na trud współczucia, a w ośrodkach

45 Ibidem.

46 T. Kanasz, I. Zielińska, op. cit.

47 T. Zbyrad, Pracownicy socjalni: od stużby człowiekowi ku wypaleniu zawodowemu. Studium socjologiczne na przykładzie województwa podkarpackiego, Kraków 2014, s. 129.

48 Ibidem. 
Pobrane z czasopisma Annales I - Philosophy and Sociology http://philosophia.annales.umcs.pl Data: 26/04/2023 12:28:37

Zmiany kultury emocjonalnej pracowników socjalnych w Polsce 155

brakuje szkoleń dotyczących radzenia sobie ze stresem ${ }^{49}$. Warto zatem rozwijać umiejętności związane z zarządzaniem emocjami, rozładowaniem napięć i frustracji, odzyskaniem poczucia kontroli oraz sensu działań.

Podsumowując przemiany kultury emocjonalnej pracowników socjalnych, należy stwierdzić, że ma ona złożony charakter. Ta złożoność polega m.in. na pewnej ambiwalencji, wynikającej z funkcji osłonowej i aktywizującej, pomocowej i kontrolnej. We współczesnym dyskursie pomocowym pojawiają się nowe kategorie wyrażające stosunek do beneficjentów, np. pojęcie empowerment, czyli upodmiotowienia, czy też pojęcie spójności, integracji społecznej. Bez zmian pozostaje jednak kategoryzacja klientów przez pracowników socjalnych na tych, którym pomoc się należy oraz tych, którzy przyjmują tzw. postawę roszczeniową. Wpływa to na bardziej lub mniej życzliwe podejście do klienta. Praca nad emocjami dokonuje się w dużym stopniu w oparciu o własne doświadczenia, korzysta się też ze wsparcia współpracowników. Wśród pracowników socjalnych rośnie świadomość zarządzania emocjami w wykonywaniu pracy socjalnej. Sprzyja temu uprawianie danego zawodu, przygotowanie do niego, a także wprowadzenie superwizji w służbach pomocy społecznej. Po latach transformacji znacząco jednak nie zmienił się prestiż zawodu pracownika socjalnego, co negatywnie może oddziaływać na kulturę emocjonalną profesjonalistów. Dotychczas w Polsce przeprowadzono kilka kampanii społecznych ocieplających wizerunek zawodu pracownika socjalnego, w tym przygotowano serial telewizyjny pt. Głęboka woda. Bez wątpienia warto kontynuować działania podwyższające prestiż tego zawodu.

\section{UWAGI KOŃCOWE}

Celem artykułu było ukazanie pomocy oraz zachowań pracowników socjalnych w Polsce w okresie transformacji systemowej w świetle koncepcji kultury emocjonalnej. Zaproponowałam autorską interpretację kultury emocjonalnej pracowników socjalnych, skupioną głównie wokół motywacji, postaw i problemów związanych z realizacją danego zawodu. Starałam się pokazać, że kultura emocjonalna profesjonalistów służących pomocą osobom potrzebującym jest złożona i zróżnicowana, uwikłana w różne konteksty instytucjonalne, strukturalne, organizacyjne i etyczne.

Jedną ze zmian, która nastąpiła w Polsce potransformacyjnej, jest uwzględnienie poczucia podmiotowości i godności beneficjentów pomocy, przynajmniej na poziomie deklaratywnym. Jest to zadanie niełatwe. Biurokratyzacja pomocy utrudnia realizację podejścia upodmiotowiającego. Inne bariery widoczne są w sytuacji

49 Ibidem, s. 343. 
pracowników, m.in. w warunkach ich pracy, niskich zarobkach, niewielkiej władzy. W przypadku starszych pracowników w grę wchodzi przyzwyczajenie się do ukształtowanego wcześniej podejścia w pracy z klientem. Ponadto stosunek do klienta zależy od przyjętej ramy ideologicznej, która przekłada się na większe współczucie lub dystans czy nawet niechęć.

Kultura emocjonalna pracowników socjalnych należy przeważnie do orientacji instytucjonalnej, ponieważ jest regulowana przez odpowiednią ustawę oraz zasady etyczne. Profesjonalistom przypisuje się dbanie o dobro klienta i podejście niedyskryminujące. Od pracowników wymaga się okazania empatii, wrażliwości na potrzeby klienta, a także sprawiedliwej i efektywnej pomocy. Złość należy poskramiać, nawet w sytuacji nieodpowiedniej (np. chamskiej) postawy klienta. Wymaga to od pracownika solidnej pracy nad emocjami. Ponadto na pracownikach socjalnych ciąży olbrzymie brzemię odpowiedzialności, a zarazem borykają się z niskim prestiżem zawodu, czasem z publicznym obwinianiem ich w dramatycznej sytuacji klientów. W praktyce zdarza się, że górę bierze orientacja impulsywna, a nie instytucjonalna. Nadmierne obarczanie pracowników odpowiedzialnością za skutki pomocy, przerost zadań biurokratycznych nad pracą socjalną, niemożność zaspokojenia potrzeb klientów oraz przeciążenie emocjonalne wynikające z dramatycznych sytuacji klientów często wywołują deformację roli zawodowej.

Wykonywanie zawodu pracownika socjalnego wiąże się z zarządzaniem stresem, którego powinno się uczyć na studiach czy szkoleniach. Umiejętne radzenie sobie w sytuacjach trudnych pozwala na lepszą pomoc oraz wyższy dobrostan pracownika i jego klienta.

\section{BIBLIOGR AFIA}

Bieńko M., Dylematy profesji i roli w refleksyjnym projekcie tożsamości współczesnego pracownika socjalnego na przykładzie pracowników powiatowych centrów pomocy rodzinie, [w:] M. Rymsza (red.), Pracownicy socjalni i praca socjalna w Polsce. Między stużba społeczna a urzędem, Warszawa 2012.

Binder P., Palska H., Pawlik W., Zaproszenie do socjologii emocji, [w:] P. Binder, H. Palska, W. Pawlik (red.), Emocje a kultura i życie społeczne, Warszawa 2009.

Czerner A., Nieroba E., Język socjologów emocji - subiektywny przewodnik, [w:] A. Czerner, E. Nieroba (red.), Studia z socjologii emocji, Opole 2011.

Florys E.M., Identyfikacja z zawodem pracowników socjalnych, „Annales UMCS. Sectio J”2016, nr 1, DOI: http://dx.doi.org/10.17951/j.2016.29.1.67.

Gordon S., Institutional and impulsive orientations in selectively appropriating emotions to self, [w:] D.D. Franks, E. Doyle McCarthy (eds.), The Sociology of Emotions, Greenwich 1989.

Gordon S., Social Structural Effects on Emotions, [w:] T. Kemper (ed.), Research Agenda for Sociology of Emotions, New York 1990.

Górniak K., Bieda $i$ wykluczenie społeczne w perspektywie (dobroczynnych) organizacji pozarzadowych, [w:] E. Tarkowska (red.), Dyskursy ubóstwa i wykluczenia społecznego, Warszawa 2013. 
Hochschild A.R., Ideology and Emotion Management: A Perspective and Path for Future Research, [w:] T.D. Kemper (ed.), Research Agendas in the Sociology of Emotions, Albany 1990.

Hochschild A.R., Zarządzanie emocjami. Komercjalizacja ludzkich uczuć, Warszawa 2009.

Kalbarczyk A., Wizje biedy i wykluczenia społecznego w praktyce polskiego systemu pomocy społecznej, [w:] E. Tarkowska (red.), Dyskursy ubóstwa i wykluczenia społecznego, Warszawa 2013.

Kanasz T., Badania emocji społecznych pracowników socjalnych, „Praca Socjalna” 2014, nr 1.

Kanasz T., Buying Food for a Hungry Person in Poland: A Case of an Internet Discussion, "Studies in Global Ethics and Global Education" 2016, Vol. 6(1).

Kanasz T., Poczucie zadowolenia z wykonywanej pracy w opiniach pracowników socjalnych, [w:] M. Mikołajczyk (red.), Pomoc społeczna i praca socjalna - różne oblicza i zadania, Warszawa 2014.

Kanasz T., Pomoc osobom doświadczającym ubóstwa w świetle socjologii emocji, „Praca Socjalna” 2016, nr 4.

Kanasz T., Zielińska I., Emotional Labour of the Polish Social Workers: The Study in Sociology of Emotions, "Polish Sociological Review" 2017, No. 3.

Kaźmierczak T., Pracownicy socjalni, kapitat ludzki, profesjonalna praktyka, [w:] M. Rymsza (red.), Pracownicy socjalni i praca socjalna w Polsce. Między stużba społeczna a urzędem, Warszawa 2012.

Kodeks Etyczny Polskiego Towarzystwa Pracowników Socjalnych, http://federacja-socjalnych.pl/ images/PDF/kodeks_etyczny.pdf [dostęp: 25.04.2018].

Łuczyńska M., Pracownicy socjalni w procesie zmian - na podstawie badań z 1988, 1995 i 2010 roku, [w:] M. Rymsza (red.), Pracownicy socjalni i praca socjalna w Polsce. Między stużba społeczna a urzędem, Warszawa 2012.

Niesporek A., Trembaczowski Ł., Warczok T., Granice symboliczne. Studium praktyk kulturowych na przykładzie działań zawodowych pracowników socjalnych, Kraków 2013.

Rymsza M., Pracownicy socjalni i praca socjalna w Polsce, [w:] M. Rymsza (red.), Pracownicy socjalni i praca socjalna w Polsce. Między stużba spoleczna a urzędem, Warszawa 2012.

Rymsza M., W stronę pracy środowiskowej i nowych ról zawodowych pracowników socjalnych, [w:] M. Rymsza (red.), Pracownicy socjalni i praca socjalna w Polsce. Między stużba społeczna a urzędem, Warszawa 2012.

Sawicka M., Pojęcie kultury emocjonalnej jako narzędzie analizy socjologicznej, „Kultura i Społeczeństwo" 2015, nr 1.

Tarkowska E., Biedni o biedzie, biedni o sobie, [w:] E. Tarkowska (red.), Dyskursy ubóstwa i wykluczenia spolecznego, Warszawa 2013.

Tarkowska E., O potrzebie uwzględnienia kultury raz jeszcze, [w:] P. Kozłowski, H. Domański (red.), Po 20 latach: polska transformacja z perspektywy ekonomicznej, socjologicznej i prawniczej, Warszawa 2010.

Trawkowska D., Pracownicy socjalni jako środowisko zawodowe. Portret czy portrety pracowników socjalnych? (komentarz), [w:] M. Rymsza (red.), Pracownicy socjalni i praca socjalna w Polsce. Między stużba spoleczna a urzędem, Warszawa 2012.

Turner J.H., Stets J.E., Socjologia emocji, Warszawa 2009.

Ustawa z dnia 12 marca 2004 r. o pomocy społecznej (Dz.U. nr 64, poz. 593).

Zbyrad T., Pracownicy socjalni: od służby człowiekowi ku wypaleniu zawodowemu. Studium socjologiczne na przykładzie województwa podkarpackiego, Kraków 2014. 
Pobrane z czasopisma Annales I - Philosophy and Sociology http://philosophia.annales.umcs.pl Data: 26/04/2023 12:28:37

\section{SUMMARY}

As the theoretical framework of this text serves the concept of Steven Gordon's emotional culture. It includes emotion dictionaries, norms, and beliefs about emotions. I am interested in some aspects of the emotional culture of professionals in the social welfare sector. The results obtained are intended to provide further discussion on the transformations of emotional culture in the sphere of help.

Keywords: sociology of emotions; assistance; Poland; emotional culture; values; emotions; social workers; transformation

\section{STRESZCZENIE}

Ramą teoretyczną niniejszego tekstu jest koncepcja kultury emocjonalnej S. Gordona. Obejmuje ona słowniki emocji, normy i przekonania wobec emocji. Interesują mnie aspekty kultury emocjonalnej profesjonalistów w sektorze pomocy społecznej. Uzyskane wyniki mają służyć dalszym dyskusjom na temat przemian kultury emocjonalnej w sferze pomocy.

Słowa kluczowe: socjologia emocji; pomoc; Polska; kultura emocjonalna; wartości; emocje; pracownicy socjalni; transformacja 